\title{
賛助会員名簿 $(2009.125)$
}

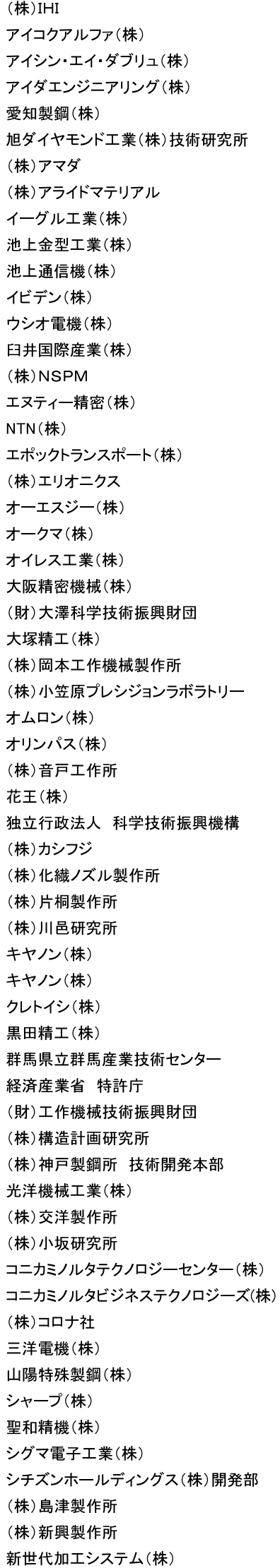

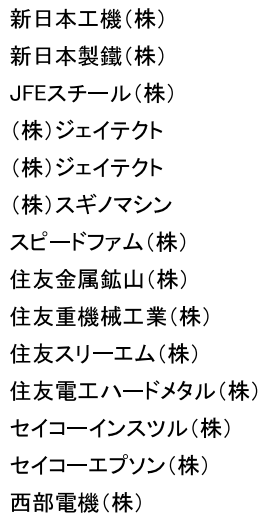

(株) 南谷製作所

日機電装(株)

日産化学工業(株)

日産自動車(株) 総合研究所

（株）日進機械製作所

日東精工(株)

(株)日平トヤマ 富山工場

日本ガイシ(株)

日本精工 (株)

日本電気 (株)

日本特殊陶業(株)

日本発条 (株)

(株)ニコン

日本キスラー(株)

(社)日本工作機械工業会

（株）日本製鋼所 広島製作所

日本電産トーソク(株)

日本電子 (株)

日本電信電話(株)フォトニクス研究所

日本特殊研砥(株)

日本ファインテック(株)

日本放送協会

日本ユニシス(株)

(株)ネオス

（株) ノリタケコーテッドアブレーシブ

(株) リリタケスーパーアブレーシブ

(株) ノリタケボンデッドアブレーシブ

(株)ハーモニック・ドライブ・システムズ

ハイウイン(株)

ハイデンハイン(株)

バンドー化学(株)生産技術センター

(株)パイロットコーポレーション 平塚工場

パナソニック(株)

パナソニック四国エレクトロニクス(株)

パナソニック電工(株)

(株) 光合金製作所

日立金属(株)生産システム研究所

日立金属(株) NEOMAXカンパニー

(株) 日立情映テック

(株)日立製作所 生産技術研究所

(株) 日立製作所 都市開発システムグループ 日立造船(株)

日立ツール(株)

日立ビアメカニクス(株)

(株)ヒロテック

(株)ビックッール

ファナック(株)

ファナック(株) 筑波工場

ファナック(株）九州支社

(株)FILWEL

(株)フジキン

(株)不二越

不二越機械工業(株)

富士精工(株)

富士通(株)

(株) 藤原製作所

扶桑化学工業 (株)

ブラザー工業(株)

HOYA(株)

ホーコス(株) 
ホンダエンジニアリング(株)

ボッシュ (株)

ポリテックジャパン(株)

牧野フライス精機 (株)

(株) 牧野フライス製作所

マコー(株)

マツダ(株)

(株)ミズホ

三鷹光器 (株)

三井精機工業(株)本社工場

(株)ミツトヨ

三菱電機(株)名古屋製作所
三菱電機 (株)生産技術センター

三菱電機メカトロニクスソフトウエア(株)

三菱レイヨン(株)生産技術研究所

武蔵エンジニアリング(株)

(株) 村田製作所 野洲事業所

明昌機工 (株)

(株) 森精機製作所

(株)安川電機

安田工業 (株)

ヤマザキマザック(株)

(株)山武

ヤマハ発動機 (株)
(株) 彌満和製作所

ユシロ化学工業(株)

リックス(株)

(株)リコー

リコーエレメックス(株)

ローレル精機 (株)

(株)ワークス

(株) 和井田製作所

(1)

新規入会の賛助会員 (2008年12月以降)

* HOYA (株)

* ハイウイン(株)

* エポックトランスポート(株)

\section{＊ 賛助会員入会のお願い *}

精密エ学会賛助会員には、以下のような特典がございます。是非、企業、団体各位のご入会をお願いいたします。

\section{賛助会員特典}

·毎月精密工学会誌の配布があり、精密機械や生産技術に関する広範な知識を得ることができます。

·英文誌(季刊)の配布があります。

·講演会、講習会、見学会、展示会などの参加費が割引になります。

·学会ホームページの会員専用サービスの利用による学会研究者との個別交流が可能です。

·学会ホームページ・賛助会員リスト経由で賛助会員ホームページヘリンクしております。

·賛助Web級につきましては、特典が異なります。

\section{入会手続き}

「入会のしおり」は、本会ホームページの「学会紹介」に掲載しており、そこから入会手続きができます。

また、郵便、FAX等での手続きをご希望の場合は、下記の会員担当に資料、申込用紙をご請求下さい。

₹102-0073

《お問い合わせ先》

東京都千代田区九段北1-5-9九段誠和ビル2F 社団法人 精密工学会 会員係

JSPEホームページURL:http://www.jspe.or.jp/

TEL:03-5226-5191 FAX:03-5226-5192

e-mail: ispe kaiin@ispe.or.jp

\section{学会事務局お問合せ先}

代表 jspejspe@jspe.or.jp

- 総合案内

会員担当 jspe_kaiin@jspe.or.jp

- 入会·退会手続き

- 所属·連絡先等変更

- 学会誌·英文誌購読

・ バックナンバー販売, 複写サービス

－会費自動引き落とし

財務·会計担当 jspe_zaimu@jspe.or.jp

- 財務·会計

. 振込連絡
大会担当 jspe_taikai@jspe.or.jp

- 春季·秋季学術講演会

- 卒業研究発表講演会

研究·国際交流担当 jspejigyo@jspe.or.jp

- 国際会議(主催·共催)

- 専門委員会·分科会

講習会担当 jspe_koushu@jspe.or.jp ·講習会関係
出版担当 jspe_shuppan@jspe.or.jp

- 会誌·英文誌への論文投稿

- 校閲状況確認

- 有料会告 (会誌)

広報·Web担当 jspe_koho@jspe.or.jp

- Webページ全般

・バナ一広告

- 有料会告 (Web)

- J-STAGE, NII関連 